\title{
Integration of Eco-centric Views of Sustainability in Port Planning
}

\author{
Xiaofang $\mathrm{Wu}^{1}$, Luoping Zhang ${ }^{2, *(\mathbb{D})}$ and Hsi-Chi Yang ${ }^{1}$ \\ 1 College of Harbour and Environmental Engineering, Jimei University, Xiamen 361021, China; \\ xiaofang.wu@jmu.edu.cn (X.W.); 201961000018@jmu.edu.cn (H.-C.Y.) \\ 2 Coastal and Ocean Management Institute, Xiamen University, Xiamen 361102, China \\ * Correspondence: lpzhang@xmu.edu.cn
}

Received: 20 January 2020; Accepted: 7 April 2020; Published: 8 April 2020

\begin{abstract}
The sustainability approach commits to conserving natural resources and biodiversity. In ports, many efforts that encourage improvement in sustainability exist, such as sustainable ports, eco-ports, or green ports. However, whether the current planning approaches for sustainable ports, eco-ports, and green ports can effectively achieve sustainability remains a question. This study aims to discuss this issue through a literature review. The main findings include (1) the current sustainable port planning following the ambitions of sustainable development and aiming to fulfill this generation's needs; (2) the eco-port planning approaches emphasizing environmental protection; (3) the planning approaches for green ports that have emerged within environmental management and give attention to the ecological issues; (4) all of the three approaches prioritizing environmental issues. We argue for the integration of eco-centric views for sustainability in port planning from a maritime supply chain perspective, and based on this, the concept of the green port is proposed. This study provides broad and mindful information regarding port sustainability education and can help foster innovation in order to face the challenges in sustainability.
\end{abstract}

Keywords: sustainable port; eco-port; green port; sustainability approach; eco-centric perspective; sustainability education

\section{Introduction}

Sustainability, the need to ensure a future for the Earth [1], emerged as the perpetuation and enhancement of the natural ecosystem in the 1970s [2]. Given the adverse impact of growth and development on global ecosystems within the limits of the biosphere's carrying capacity, the Brundtland report set a blueprint for sustainability to achieve economic growth, social responsibility, and environmental quality in 1987 [3]. The United Nation's 2030 Agenda currently interprets sustainability as the maintenance of well-being, which concerns prosperity, planet, and people and seeks the continuity of ecological systems and values irreplaceable natural resources [4]. Exploring the theoretical basis of these concepts, eco-centrism, which includes humanity and the natural ecosystem as a whole and views all life as equal, has been recognized [5]. Understanding the fact that the natural environment and resources are fundamental for human existence and development, this eco-centric approach became a key move towards sustainability [6]. Human activities must be connected in order to conserve natural resources and biodiversity as a result of the changing environment and the loss of biodiversity [5,7]. Taking the case of maritime activities, the World Association for Waterborne Infrastructure (PIANC) laid stress on the "working with nature philosophy" to exploit the ecosystem-based solutions for sustainability [8].

Due to pressures from environmental non-government organizations, stakeholders, and the public, industries, including the port industry, have integrated sustainability into their business reports $[9,10]$. 
Many port sustainability issues, such as energy-saving, air quality, emission-reducing, natural resources conservation, and waste handling, have been raised by international organizations, governments, port authorities, and companies [11]. In recent decades, well-known initiatives of sustainable ports, eco-ports, and green ports have been developed and implemented to address growing port sustainability concerns $[10,12-14]$. When moving towards the long-term goal of sustainability, port planning has been regarded as a critical tool in port development [15]. However, the literature rarely concerns the sustainability-oriented planning approach in ports [16]. There is a question about whether the current planning efforts of sustainable ports, eco-ports, and green ports employ the eco-centric approach to encourage the achievement of sustainability.

Thus, this study aims to review the current approaches of planning for sustainable ports, eco-ports, and green ports, and to identify if the existing ones can capture the ecological requirements of sustainability. The exploration of sustainability in ports may not only help the development of creative perspectives but also help direct decision-makers to provide effective strategies for ensuring sustainability in ports.

\section{Materials and Methods}

\subsection{Methods}

The literature review, an evidence-based approach, has been known as a key scientific tool to help develop a knowledge base for an academic inquiry [17]. A structured literature review, which includes the processes of collecting data, refining the initial search results, and analyzing the remaining literature, has become popular for its transparent and replicable work [18]. This study adopts a structured literature review method to identify and manage the literature, and employs content analysis to discern reliable findings and give rise to a discussion [18]. In this research, there are two data sources-one is searched publications from the Scopus database for its broad coverage, and the other is from the official websites of international, regional, and local organizations selected by experts consulting from representative perspectives of the green port, sustainable port, and eco-port (see Table 1). Keywords of "green port", "sustainable port", and "eco-port" combined with "planning", separately, were used for the two-part search.

Table 1. Selected official websites for data collection.

\begin{tabular}{|c|c|c|}
\hline Types & Organizations & Official Websites \\
\hline International & $\begin{array}{l}\text { United Nations Conference on Trade and Development } \\
\text { (UNCTAD) } \\
\text { The World Association for Waterborne Infrastructure } \\
\text { (PIANC) } \\
\text { GreenPort } \\
\text { International Association of Ports and Harbors (IAPH) } \\
\text { European Sea Ports Organization (ESPO) }\end{array}$ & $\begin{array}{c}\text { https://unctad.org/en/Pages/Home.aspx } \\
\text { https://www.pianc.org/ } \\
\text { https://www.greenport.com/ } \\
\text { https://www.iaphworldports.org/ } \\
\text { https://www.espo.be/ }\end{array}$ \\
\hline National & $\begin{array}{l}\text { United States Environmental Protection Agency } \\
\text { Ministry of Transport of the People's Republic of China } \\
\text { Maritime and Port Authority of Singapore }\end{array}$ & $\begin{array}{c}\text { https://www.epa.gov/ } \\
\text { http://www.mot.gov.cn/ } \\
\text { https://www.mpa.gov.sg/web/portal/home }\end{array}$ \\
\hline Local & $\begin{array}{c}\text { Port of Long Beach } \\
\text { Port of Los Angeles } \\
\text { Port of New York and New Jersey } \\
\text { Port of San Diego } \\
\text { Port of Rotterdam } \\
\text { Sydney Ports Corporation }\end{array}$ & $\begin{array}{c}\text { http://www.polb.com/ } \\
\text { https://www.portoflosangeles.org/ } \\
\text { http://www.panynj.gov/ } \\
\text { https://www.portofsandiego.org/ } \\
\text { https://www.portofrotterdam.com/en } \\
\text { https://www.service.nsw.gov.au/ }\end{array}$ \\
\hline
\end{tabular}

\subsection{Materials}

As of 2 January 2020, the Scopus search collected 141, 1, and 22 English and Chinese papers for sustainable port planning, eco-port planning, and green port planning, respectively. After excluding the publications classified as research areas in the Scopus database of (1) Earth and Planetary Sciences, (2) Energy, (3) Computer Science, (4) Agricultural and Biological Sciences, (5) Mathematics, (6) Materials Science, (7) Arts and Humanities, (8) Biochemistry, Genetics, and Molecular Biology, (9) Chemistry, 
(10) Physics and Astronomy, (11) Immunology and Microbiology, and (12) Medicine, there were 83, 1 , and 13 papers that remained for data analysis. Additionally, the official website search identified 15 documents associated with planning for the sustainable port, eco-port, and green port.

\section{Results}

\subsection{Current Concepts of the Sustainable Port, Eco-Port, and Green Port}

The United Nations Conference on Trade and Development (UNCTAD) linked sustainable development, which was defined by the World Commission on Environment and Development, to ports in 1993 [19]. Since then, sustainable ports have drawn much attention regarding the environment and development for satisfying humans' needs. In 2013, the Working Group of the World Association for Waterborne Infrastructure (PIANC) suggested that sustainable ports should be based on "an economic green growth strategy", "working with nature philosophy", "corporate social responsibility", and "stakeholder participation" [12]. As with eco-ports, the European Sea Ports Organization (ESPO) initiated a project entitled EcoPorts, which emerged as a port that coexisted with the environment [20], and highlighted the awareness of environmental protection and the improvement of environmental management $[14,20]$. Entering the 21st century, the concept of the "green port" has been widely accepted as the balance of environmental challenges and economic demands, and the Working Group of the PIANC proposed that green ports should "understand the environment and human uses" and "work with nature philosophy" [8].

\subsection{Efforts of Sustainability Planning in Ports}

As early as 1993, the United Nations Conference on Trade and Development (UNCTAD) initially proposed policies and strategies for sustainable development in ports [19], and the EcoPorts Tools and Certification scheme was implemented in Europe [21]. In 2000, the Urban Harbors Institute (UHI) at the University of Massachusetts, Boston, provided some planning suggestions regarding environmental management and technology for America's green ports [13]. In the past two decades, world associations and regional governments have paid much attention to providing guidance for the planning of green ports, sustainable ports, and eco-ports [8,22], and many related planning efforts for individual ports, like the Port of Long Beach and the Port of San Diego, have been conducted [23,24].

Additionally, scholars have paid attention to analyzing and evaluating the current status of environmental performance in ports and provided indicators of and ideas for sustainable or green port planning [25]. Guos Ong et al. [26] and Wu [27] tried to integrate ecological planning views into green port planning.

\subsection{Approaches to Port Planning for Sustainability}

Based on the papers and documents obtained, the approaches for sustainable port planning, eco-port planning, and green port planning can be summarized here.

(1) Sustainable port planning:

- The UNCTAD provided the planning approach of sustainable development for ports in 1993, which includes project objectives; the pre-feasibility study of the initial environmental assessment; feasibility study; environmental impact assessment, formulation, adoption, implementation, and monitoring or evaluation [19].

- The PIANC offered guidance for port authorities to build sustainable ports in 2013, which embraces defining sustainable ports to meet the needs of present and future generations, analyzing the roles of port authorities, identifying the environmental and sustainability issues in ports and related logistic chains, and strategies formulation [8,12].

- A World Ports Sustainability Program was set up in 2018 by the International Association of Ports and Harbors (IAPH) in order to implement the United Nation's Sustainable Development Goals 
(SDGs) [28]. This program will communicate the missions and objectives, and develop further projects and initiatives [28].

(2) Eco-port planning:

- The ESPO provided a certification scheme for eco-ports, which includes the processes of self-diagnosis, port environmental review, and certification [21]. In 2012, the Green Guide was published by the ESPO in order to structure the approach for port environmental management and sustainability, which comprises setting a vision to improve environmental performance and environmental management [29].

- In 2011, the Port of Osaka provided a planning model for eco-ports, which includes protecting the natural environment and minimizing the environmental damages caused by port development [20].

(3) Green port planning:

- The Urban Harbors Institute at the University of Massachusetts, Boston, presented an approach for the environmental management of America's green ports in 2000, which includes avoiding, preventing, minimizing, mitigating, or remediating the environmental impacts related to port development and operations [13].

- The Port of Long Beach provided policies for a green port in 2005, by adopting specific environmental principles, setting goals, establishing specific metrics to measure progress toward meeting the goals, designing environmental programs, and making specific incentives and legislative proposals [23].

- The Port of Sydney offered guidelines for green port construction in 2006, which provide strategies and practices to be both environmentally friendly and commercially viable [30].

- The San Diego Unified Port District set goals and objectives in the areas of improving water quality, conserving energy, reducing air emission and waste, implementing a sustainable building, and increasing employees and the public's sustainable awareness, so as to build a green port in 2008 [24].

- In 2010, the Maritime and Port Authority of Singapore encouraged ocean-going vessels to reduce emissions such as sulfur oxides and nitrogen oxides, and use clean fuels for achieving a green port [31].

- The Ministry of Transport of the People's Republic of China provided opinions to promote the sustainable development of coastal ports in 2011, which proposes green strategies including energy-saving, emission-reducing, and ecological protection based on the identification of the problem [22]. Another opinion provided green strategies for a green port by the Ministry of Transport, which include resources-saving, energy efficiency improvement, emissions-controlling, and environmental protection based on the development goals set by the government [32]. In 2018, the Ministry of Transport provided an action plan draft to promote green port construction (2018-2022) in 2018, which proposed green development strategies including low carbon and circular, resource conservation, pollution prevention, and ecological protection based on the development goals set by the governments [33].

- The Department of Transportation of Jiangsu Province, China, issued the Three-Year Action Plan for the Construction of green ports in Jiangsu Province (2018-2020) in 2014, and this proposed green actions including energy saving, emission reduction, pollution prevention, and shoreline resource protection to implement the national strategies [34].

- The Green Port Action Plan (2014-2020) issued by the Department of Transportation of Guangdong Province, China, in 2014 [35], and the Shanghai Green Port Three-Year Action Plan issued by the Port of Shanghai in 2015 [36], proposed green actions including energy saving, emission reduction, and pollution prevention, so as to implement the national strategies.

- The Port of Xiamen of China issued the thirteenth Five-Year Plan for constructing the green port in the Port of Xiamen in 2019, which proposed green strategies including resource conservation, 
environmental friendliness, and social responsibilities for protecting the environment and ecology in the port area through an assessment of status [10].

We can acknowledge that the current sustainability approaches in port planning are problem-/data-driven or vision-/goal-oriented. The problem- or data-driven approaches mainly rely on the assessment of the impact of port activities and can be characterized as bottom-up. The visionor goal-oriented approaches have been widely used in planning by international organizations and associations, governments, and port authorities. Most of the top-down approaches have offered strategies or actions to implement sustainable ports, eco-ports, and green ports. Both approaches highlight environmental issues.

\section{Discussion}

According to the literature review, the initiatives of sustainable ports and eco-ports emerged earlier than those of green ports. All of these concepts give much attention to environmental issues, and recent ideas of sustainable ports and green ports use a "work with nature philosophy" [8,12]. For guiding these port developments, plenty of practical planning for sustainable ports, eco-ports, and green ports from international, regional, and local organizations have been identified, while only a few papers have focused on port sustainability planning. Probably because of different systems of port governance in different areas, for instance, the Ministry of Transport of the People's Republic of China provided national strategies to plan a sustainable or green port [22], but the most green or sustainable efforts in the United States were in the private sector [23]; the current port sustainability-oriented planning was lacking a coherent policy. Nevertheless, through the bottom-up problem-/data-driven or top-down vision-/goal-oriented planning processes, sustainable port planning has followed the requirements of sustainable development and attempted to fulfill the needs of present and future generations. Compared with eco-port planning, which commits to improving environmental performance [37], green port planning, to some extent, is concerned with natural conservation [10] and ecological protection [33]. The distinction between the two approaches concerns the development objectives and the satisfaction of human needs or the maintenance of the natural ecosystem's intrinsic value [5]. Taking sustainability education as an example, for the former, people would be educated to protect the environment to serve human interests, rather than the "unity of nature and humanity" from ancient Chinese philosophy.

However, according to the previous studies by Wu, Zhang, and Luo [18], a combination of top-down strategic focuses with bottom-up assessment information is necessary in order to improve planning effectiveness, for overcoming the limitations of relying mainly on either limited data or the planners' subjective judgment. In addition, even though some organizations such as the PIANC started to relate logistics chain concerns with port planning, the majority of current approaches still concern the port itself. Owing to ports being the nodes of logistics chains in the context of globalization and larger-sized vessels, port sustainability planning should do more work on the collaborative research-practice maritime supply chain to guide the maritime industry towards sustainability.

Moreover, the conservation of natural ecosystems has already been considered as the key to sustainability, based on the fact that "planet Earth is an end-in-itself" [38], and that people are part of nature and ecosystems [39]. Based on the review results, we found that the current sustainability approaches for port planning have limitations for capturing the ecological essence of sustainability. The current sustainable port planning views, aimed at the fulfillment of human needs, make it difficult to maintain natural resources because of human preferences. Planning for eco-ports recently failed to prioritize nature conservation [37], which may lead to the slow progress of the sustainability approach. Although green port planning raised ecological awareness, a sustainability approach, namely green development, has not been realized. The green development approach has been proven as a good choice for achieving sustainability by $\mathrm{Wu}$, Zhang, and Luo [5], because of its eco-centric theoretical bases, and the objective of conserving the natural resources and biodiversity. Fortunately, in 1998, the preferred sustainability approach was implemented in the real estate industry so as to 
integrate ecology into construction [40]. Some countries and cities have also used green development to transform their developments; for instance, China has made green development a development path [41].

In this study, we suggest the green port as a good approach towards sustainability, and the combination of green development in the theoretical bases and objectives may lead to more specific and mindful implications, as follows:

- Integrating ecological issues such as biodiversity [10], natural resources conservation [10], and ecological risks caused by oil spoil and non-routine discharges in port development.

- Considering the logistic chain from a supply place to a receipt place [42] in port scoping to improve connectivity and add value [43].

- Combing the top-down strategic sustainability goal with the scientific bottom-up assessment information for port planning.

\section{Conclusions}

In globalization and global sustainability, challenges drive practitioners and researchers to develop proactive and collaborative planning for sustainability in ports. Currently, there is a lack of consistent or coherent policy for port sustainability-oriented planning. This study contributes to the review and discusses the existing representative sustainability approaches for port planning. Insights from our broad literature review indicate the following: (1) the current sustainability approaches in port planning are limited to specific problems, historical data, and subjective judgment for port-itself development; (2) approaches for sustainable port planning, eco-port planning, and green port planning prioritized the environmental issues, but ignored the importance of ecological matters; (3) the current planning approaches for sustainable ports, targeted to meet the needs of present and future generations, are not a good choice for sustainability; (4) green port planning did not realize the implications of green development on the sustainability of nature. Through a comparison of the current sustainability approaches for port planning, we adopted green port planning as a preferred approach for sustainability and gave more mindful connotations for consideration.

This study provides a meaningful analysis to help decision-makers and students understand the current status of port sustainability planning, and prompts in-depth thinking about sustainability in ports. Nonetheless, we would like a broader and further discussion on this topic to gradually move towards the long-term goal of sustainability. For this, innovative sustainability education must play a vital role.

In the future, the proposed concept of a green port will impact the establishment of the subsequent approaches and methods from planning areas, planning objectives, planning processes, and priority initiatives perspectives. A collaborative and cooperative research-practice network in port, shipping, and maritime logistics will be of help. A wider discussion would also be to think of other elements by using Key Performance Indicators, such as economic impact and technological innovation, to learn more about port sustainability planning. Furthermore, for better education about sustainability in ports, a lot of ethical searches into current research and practices need to be carried out, which may encourage creative thinking.

Author Contributions: L.Z. designed and oversaw the research. X.W. collected information and drafted the manuscript. H.-C.Y. reviewed and commented. All authors have read and agreed to the published version of the manuscript.

Funding: This study was funded by the National Public Welfare Research Project of State Oceanic Administration of China (grant number 200905005) and the Jimei University Scientific Research Starting Foundation (grant number ZQ2019037).

Acknowledgments: We thank three anonymous reviewers for informative comments and suggestions on an early version of this manuscript.

Conflicts of Interest: The authors declare no conflict of interest. 


\section{References}

1. Future Earth. Future Earth Initial Design: Report of the Transition Team. Available online: http://futureearth. org/sites/default/files/Future-Earth-Design-Report_web.pdf (accessed on 15 May 2019).

2. International Union for Conservation of Nature. Tenth General Assembly. Available online: https: //portals.iucn.org/library/efiles/documents/ns-sp-027.pdf (accessed on 16 January 2020).

3. World Commission on Environment and Development. Report of the World Commission on Environment and Development: Our Common Future; United Nations: Geneva, Switzerland, 1987.

4. United Nations Conference on Environment and Development. Transforming our World: The 2030 Agenda for Sustainable Development. Available online: https://sustainabledevelopment.un.org/post2015/ transformingourworld/publication (assessed on 25 July 2018).

5. Wu, X.; Zhang, L.; Luo, M. Discerning sustainability approaches in shipping. Environ. Dev. Sustain. 2019. [CrossRef]

6. Washington, H.; Taylor, B.; Kopnina, H.; Cryer, P.; Piccolo, J.J. Why ecocentrism is the key pathway to sustainability. The Ecol. Citiz. 2017, 1, Y-Z.

7. Rands, M.R.W.; Adams, W.M.; Bennun, L.; Butchart, S.H.M.; Clements, A.; Coomes, D.; Entwistle, A.; Hodge, I.; Kapos, V.; Scharlemann, J.P.W.; et al. Biodiversity conservation: Challenges beyond 2010. Science 2010, 329, 1298-1303. [CrossRef] [PubMed]

8. PIANC (World Association for Waterborne Transport Infrastructure). Sustainable Maritime Navigation. Available online: http://www.imo.org/en/OurWork/Environment/LCLP/recentevents/Documents/PIANC\% 20report\%20for\%20SG37.pdf (accessed on 12 October 2018).

9. Joensuu, K.; Koskela, M.; Onkila, T. Social proximity and environmental NGO relationships in corporate sustainability reports. Sustain. Dev. 2015, 23, 26-40. [CrossRef]

10. Wu, X.; Zhang, L.; Dong, Y.-W. Towards sustainability in Xiamen harbor, china. Reg. Stud. Mar. Sci. 2019, $27,100552$. [CrossRef]

11. Breitling, U. Sustainable Shipping and Port Development; 5th Regional EST Forum in Asia; Deutsche Gesellschaft für Technische Zusammenarbeit (GTZ) GmbH: Bangkok, Thailand, 2010.

12. PIANC. WG150 Sustainable ports-A Guidance for Port Authorities. Available online: http://www1. iaphworldports.org/pdf/PIANC_WG150.pdf (accessed on 12 October 2018).

13. Urban Harbors Institute. America's green ports: Environmental management and technology at US ports. Available online: http://scholarworks.umb.edu/cgi/viewcontent.cgi?article=1033\&context=uhi_pubs (accessed on 2 January 2020).

14. ESPO (European Sea Ports Organization). Ecoports. Available online: http://www.ecoports.com/ (accessed on 2 January 2020).

15. Gaur, P. Port Planning as a Strategic Tool: A Typology; University of Antwerp: Antwerp, Belgium, 2005.

16. Davarzani, H.; Fahimnia, B.; Bell, M.; Sarkis, J. Greening ports and maritime logistics: A review. Transp. Res. Part D Transp. Environ. 2015, 48, 473-487. [CrossRef]

17. Tranfield, D.; Denyer, D.; Smart, P. Towards a methodology for developing evidence-informed management knowledge by means of systematic review. Br. J. Manag. 2003, 14, 207-222. [CrossRef]

18. Wu, X.; Zhang, L.; Luo, M. Current strategic planning for sustainability in international shipping. Environ. Dev. Sustain. 2018, 22, 1729-1747. [CrossRef]

19. UNCTAD (United Nations Conference on Trade and Development). Sustainable Development for Ports. Available online: http://unctad.org/en/Docs/sddport1_en.pdf (accessed on 2 January 2020).

20. Puig, M.; Darbra, R.M. The role of ports in a global economy, issues of relevance and environmental initiatives. In World Seas: An Environmental Evaluation; Elsevier: Amsterdam, The Netherlands, 2019; pp. 593-611.

21. Darbra, R.M.; Ronza, A.; Casal, J.; Stojanovic, T.A.; Wooldridge, C. The self diagnosis method: A new methodology to assess environmental management in sea ports. Mar. Pollut. Bull. 2004, 48, 420-428. [CrossRef] [PubMed]

22. Ministry of Transport of the People's Republic of China. Opinions on Promoting the Healthy and Sustainable Development of Coastal Ports. Available online: http://www.gov.cn/gongbao/content/2012/content_2137653. htm (accessed on 11 September 2019).

23. Port of Long Beach. Green Port Policy. Available online: http://www.polb.com/environment/green_port_ policy.asp (accessed on 2 October 2018). 
24. Board of Port Commissioners. Green Port Program. Available online: https://www.portofsandiego.org/ environment/green-port.html (accessed on 25 September 2019).

25. Schipper, C.A.; Vreugdenhil, H.; de Jong, M.P.C. A sustainability assessment of ports and port-city plans: Comparing ambitions with achievements. Transp. Res. Part D Transp. Environ. 2017, 57, 84-111. [CrossRef]

26. Guos Ong, D.; Hou Ming, F.; Wen Hua, W. The analysis of target system constitution of china's low carbon green port. J. Wuhan Univ. Technol. (Soc. Sci. Ed.) 2011, 24, 672-675.

27. Wu, X. The Research of Green Port Planning Theories and Methods. Master's Thesis, Ocean University of China, Qingdao, China, 2014. (In Chinese).

28. International Association of Ports and Harbors. World Ports Sustainability Program (WPSP) Charter. Available online: https://sustainableworldports.org/wp-content/uploads/wpsp-declaration.pdf (accessed on 15 December 2018).

29. ESPO (European Sea Ports Organization). Green Guide. Available online: http://www.ecoports.com/templates/ frontend/blue/images/pdf/espo_green\%20guide_october\%202012_final.pdf (accessed on 2 January 2020).

30. Sydney Ports Corporation. Green Port Guidelines. Available online: https://www.portauthoritynsw.com.au/ corporation/media_and_publications/publications/environment/environment/green_port_guidelines_ 2006 (accessed on 2 October 2018).

31. Lam, J.S.L.; Notteboom, T. The greening of ports: A comparison of port management tools used by leading ports in asia and europe. Transp. Rev. 2014, 34, 169-189. [CrossRef]

32. Ministry of Transport of the People's Republic of China. Guiding Opinions of Promoting the Development of Transportation to be Green, Circular and Low Carbon. Available online: http://www.gov.cn/gongbao/ content/2013/content_2466586.htm (accessed on 2 January 2020).

33. Ministry of Transport of the People's Republic of China. In-depth Promotion of Green Port Construction Action Plan (2018-2022) (draft for comments). Available online: https://wenku.baidu.com/view/ 0bd6c0a54a35eefdc8d376eeaeaad1f3469311d6.html (accessed on 25 September 2019).

34. Department of Transportation of Jiangsu Province. Three-Year Action Plan for the Construction of Green Ports in Jiangsu Province (2018-2020). Available online: http://wxjtj.wuxi.gov.cn/doc/2018/09/10/1934301.shtml (accessed on 25 September 2019).

35. Department of Transportation of Guangdong Province. Green Port Action Plan (2014-2020). Available online: http://www.doc88.com/p-7364287034228.html (accessed on 25 September 2019).

36. Shanghai Municipal People's Government Office. Shanghai Green Port Three-Year Action Plan; Shanghai Municipal People's Government Office: Shanghai, China, 2015.

37. Puig, M.; Wooldridge, C.; Michail, A.; Darbra, R.M. Current status and trends of the environmental performance in European ports. Environ. Sci. Policy 2015, 48, 57-66. [CrossRef]

38. Piccolo, J.J. Intrinsic values in nature: Objective good or simply half of an unhelpful dichotomy? J. Nat. Conserv. 2017, 37, 8-11. [CrossRef]

39. The Economics of Ecosystems and Biodiversity. The Economics of Ecosystems and Biodiversity in Local and Regional Policy. Available online: https://www.routledge.com/The-Economics-ofEcosystems-and-Biodiversity-in-Local-and-Regional-Policy/Wittmer-Gundimeda/p/book/9781849712521 (assessed on 16 January 2020).

40. Rocky Mountain Institute. Green Development: Integrating Ecology and Real Estate; John Wiley \& Sons, Inc.: Hoboken, NJ, USA, 1998.

41. National Development and Reform Commission of the People's Republic of China. The 13th Five-Year Plan for Economic and Social Development of The People's Republic of China; Central Compilation \& Translation Press: Beijing, China, 2016.

42. Wu, X.; Zhang, L.; Feng, H. Green strategic planning approach for international shipping activities. Sustainability 2019, 12, 41. [CrossRef]

43. PIANC. Port Master Planning: Guidelines for Existing Ports. Available online: http://www.eaumer-fleuves.cerema.fr/IMG/pdf/Port_masterplanning_-_guidelines_for_existing_ports_cle699aff.pdf (accessed on 13 October 2018).

(C) 2020 by the authors. Licensee MDPI, Basel, Switzerland. This article is an open access article distributed under the terms and conditions of the Creative Commons Attribution (CC BY) license (http://creativecommons.org/licenses/by/4.0/). 